\title{
Studies on Circo and Polyoma Viruses in Psittacine Birds in Egypt, During 2014-2016
}

\author{
El_Shahidy $\mathbf{M}^{\mathbf{1}}$ and Helal $\mathbf{I}^{\mathbf{2}}$, Noaman $\mathbf{S}^{\mathbf{2} *}$ \\ 1- Department of Virology, Faculty of Veterinary Medicine, Suez Canal \\ University, Ismailia, Egypt. ${ }^{2-}$ General Directorate of Veterinary Quarantine \\ and Inspection for East and Sinai, Veterinary Quarantine, Port Said \\ * Corresponding author: Suzy Noaman, e mail: Suzy_Noaman@yahoo.com
}

\begin{abstract}
:
In recent years various psittacine birds have been popular and kept as pet animals in Egypt. Circo and Polyomaviruses and are the main causative agents of Psittisine beak and feather deformities. The main objectives of this study were centered on DNA virus infections in psittacine birds with special refreance to Circovirus and Polyomaviruses. Feather and tissue samples were collected from infected birds and examined using PCR based technology.A total of 50 infected Psittacine birds were examined in which feather and tissue sample were collected and screened for the presence Circo and Polyomaviruses by using PCR technology. PCR was used to amplify $\mathrm{C} 1$ gene of Circovirus and T gene of polyomavirus in extracted DNA. The highest prevalence of Circovirus infection in feather samples was shown in red rumped parakeet followed by budgerigar and love birds (41.66, 26.92 and 33.33; respectively). The distribution rate of polyomavirus infection in parakeet, budgerigar and love birds were 23 $\%, 23.7 \%$ and $16.66 \%$ respectively..Co-infection with Polyoma and Circovirus, was detected in, three parakeet, six budgerigars and two love birds with a total percentage of $22 \%$. Apparently healthy psittacine birds can be latently infected with either or both Circo and Polyomavirus without showing any clinical symptoms, and become carriers for and virus shedding disease transmission to other birds. In future studies in Egypt, an attempt to isolate Circo and Polyoma viruses from field cases should be done and the isolates could use for development of bivalent prophylactic vaccine for Egyptian psatticine birds.
\end{abstract}

Keywords: psittacine birds, polyomavirus, psittacine beak and feather virus, PCR.

\section{Introduction:}

In recent years various psittacine birds have been popular and kept as pet animals in Egypt. Infectious diseases of psittacine birds especially viral diseases are the most common clinical problems in captive psittacine birds because of 
difficulties in treatment and control and their association with acute death and deformities in peak and feathers (Ritchie et al., 2003).

Many viral infections in psittacine birds have been reported worldwide including DNA and RNA viruses. DNA virus infections associated with high morbidities and mortalities in psittacine birds including, psittacine beak and feather disease (PBFD) caused by Circovirus infection (Pass and Perry, 1984), avian Polyomavirus infection (Bernier et al. 1981), psittacid Herpesvirus infection (Simpson et al., 1975), psittacine Adenovirus infection (Raue et al., 2005), Poxvirus infection (McDonald et al., 1981) and Papillomavirus infection (Cooper et al., 1986). Concerning to RNAvirus infections in psittacine birds were including, Reovirus infection (van den Brand et al., 2007), Coronavirus infection (Gough et al., 2006), Paramyxovirus infection (Grund et al., 2002), Influenzavirus infection (Pillai et al., 2008) and Bornavirus infection (Kistler et al., 2008).

Circo and Polyomaviruses represent the most prevalent cause of feather and beak deformities in psittacine birds with two different disease syndrome. Psittacine beak and feather disease (PBFD) caused by Circovirus and Budgerigar fledgling disease (BFD) caused by avian Polyomavirus. PBFD is widely distributed in many countries of the world, as Australia (Khalesi et al., 2005). PBFD has been confirmed in over 60 species of both free ranging and captive psittacine birds (Todd, 2004).

In Egypt information about the incidence and prevalence of beak and feather disease \& Budgerigar fledgling disease in psittacine birds are poorly understand hence this study considered a preliminary to understand the virus causes of feather and beak losses and dystrophy that affect beak and feather of psittacine birds in Egypt. The main objectives of this study were centered on DNA virus infections in psittacine birds with respect to Circovirus and Polyomaviruses the main causative agents of Psittacine beak and feather deformities. To achieve this work, feather and tissue samples were collected from infected birds to evaluate the incidence of both viruses in psittacine birds in Egypt using PCR based technology and histopathology.

\section{Materials and Methods:}

\section{Psittacine birds}

Examined Thirty apparently healthy birds and twenty clinically affected dead birds suffering from loss of appetite, vomiting, diarrhea and feather deformities were collected. The examined birds included: 26 budgreigars, twelve red rumped parakeets, and twelve love birds. Dead birds were examined clinically and for post mortem lesions. Bird samples were collected over a period of three years starting from 2014 and ending early 2016 All samples were 
collected from Port Said provinces at different localities.

\section{Feather and tissue samples}

Feathers and tissues from clinically affected dead birds and apparently healthy birds were collected. Feather samples were plucked from the chest area of juvenile and adult birds. Liver, spleen and intestine were collected from diseased birds

\section{DNA extraction}

DNA was extracted from feathers and tissues samples using QIA amp DNA minikit (Qiagen), Catalouge No.51304. QIA DNA minikit combines the selective binding properties of a silica gel based membrane according to manufacture instructions with the speed of the microcentrifuges.

\section{PCR for Circovirus}

PCR amplification of ORF1 fragment of $202 \mathrm{bp}$ in length, as described by Raue et al. (2004). The sequence of primers was as follows: P2-5'-AAC CCT ACA GAC GGC GAG-3' (182-199) and P4-5'-GTC ACA GTC CTC CTT GTA CC-3' (879-898) using the HotStar Taq ${ }^{\circledR}$ Plus Master Mix PCR kit (QIAGEN, Hilden, Germany). Each reaction tube contained 1 unit of HotStar Taq ${ }^{\circledR}$ Plus DNA polymerase in $1 \times$ PCR buffer containing ( $\mathrm{KCl}$ and (NH4)2SO4), 200uM of each dNTP, $0.5 \mu \mathrm{M}$ of each of the forward and reverse primers, $1 \times$ CoralLoad dye mix, and $3 \mu 1$ of the sample DNA and controls. Thermal cycling conditions for amplification of circoviral genes were: an initial denaturation step $\left(95^{\circ} \mathrm{C}\right.$ for $\left.4 \mathrm{~min}\right)$, amplification cycles $\left(95^{\circ} \mathrm{C}\right.$ for $30 \mathrm{sec}, 54.5^{\circ} \mathrm{C}$ for $30 \mathrm{sec}$, and $72^{\circ} \mathrm{C}$ for $50 \mathrm{sec}$ ), and a final extension step $\left(72^{\circ} \mathrm{C}\right.$ for $\left.5 \mathrm{~min}\right)$.

\section{PCR for Polyomavirus}

PCR amplification of a 310 bp fragment of the APV genome was performed using primers described by by Johne and Müller (1998) The sequence of primers was as follows: 5'-CAA GCA TATGTC CCT TTA TCC C-3'(4303-4324) and 5'-CTGTTT AAG GCC TTC CAA GAT G -3' (4,6124,591).using the HotStar Taq ${ }^{\circledR}$ Plus Master Mix PCR kit (QIAGEN, Hilden, Germany). Each reaction tube contained 1 unit of HotStar Taq ${ }^{\circledR}$ Plus DNA polymerase in $1 \times$ PCR buffer containing ( $\mathrm{KCl}$ and (NH4)2SO4), 200uM of each dNTP, $0.5 \mu \mathrm{M}$ of each of the forward and reverse primers, $1 \times$ CoralLoad dye mix, and $3 \mu 1$ of the sample DNA and controls. Thermal cycling conditions for amplification of polyma virus genes were: an initial denaturation step $\left(95^{\circ} \mathrm{C}\right.$ for $\left.4 \mathrm{~min}\right)$, amplification cycles $\left(95^{\circ} \mathrm{C}\right.$ for $30 \mathrm{sec}, 54.5^{\circ} \mathrm{C}$ for $30 \mathrm{sec}$, and $72^{\circ} \mathrm{C}$ for $50 \mathrm{sec}$ ), and a final extension step $\left(72^{\circ} \mathrm{C}\right.$ for $\left.5 \mathrm{~min}\right)$. Sequencing and Phylogenetic analysis

Purified PCR products were sequenced in the foreword and reverse directions on an applied biosystem 3130 automated DNA sequencer (ABI 3130, USA) using a ready reaction Bigdye terminator $\mathrm{V}$ 3.1 cycle sequencing kits (Perkin Elmer/applied biosystem, Forster city, CA. Cat. No.4336817). The generated sequences were uploaded 
to the gene bank to establish the similar sequences elsewhere all over the world. Blast analysis were done using geneious softwere in comparison to the generated sequences. Strains identified were aligned with other strains obtained from gene bank using MAFFT alignment (Standly et.al, 2013). Comparative analysis of the sequences was performed using Clustal V multiple sequence alignment program, version 1.83 of MegAlign module of Lasergene DNA star software pairwise Phylogenetic tree were constructed using Mega 5.10 program with neighbor joining method (Tamura et al., 2011).

\section{Results}

Amplification of $\mathrm{C} 1$ gene of Circovirus in psittacine birds using PCR

Total DNA extracted from 50 pooled feather sample and pooled tissue samples were used as template for amplification. The predicted band size for these primers were a PCR product with a size of 202 bp (Fig. 1). Total positivity percentage of Circovirus in pooled feather and skin samples (32\%) is higher than pooled tissue samples $(20 \%)$. The highest prevalence of Circovirus infection in feather samples was shown in red rumped parakeet followed by budgrigar and love birds with positivity \% of $41.66,26.92$ and 33.33 respectively.

Sequence analysis of $\mathrm{C} 1$ gene of Psittacine Circovirus

\section{Nucleotide sequence}

Sequencing and analysis of PCRpositive samples to Circovirus from red rumped parakeet in Egypt were amplified typical fragments of $\mathrm{C} 1$ gene of Circovirus genome. Analysis of the nucleotide sequence of Egyptian Circovirus showed that, the sequence was 202 nucleotides long. Blast analysis of $\mathrm{C} 1$ gene fragment of psittacine Circovirus in gene bank revealed 10 similar sequences in USA and Italy with their accession numbers (Fig 2). When nucleotide sequence of $\mathrm{C} 1$ gene of Circovirus were compared to other sequences in gene bank showed 95.5-100\% identity and identical to other described Circoviruses elsewhere. Comparative nucleotide sequence analysis of red rumped parakeet strain with ten previously published strains was performed (Table 1). Compared with the consensus sequence showed two nucleotide exchanges at positions 16 and 126 but not effect on amino acid translation (Fig 2).

\section{Amino acid sequence}

$\mathrm{C} 1$ gene nucleotide sequence of psittacine Circovirus were translated into amino acids and compared with other 10 sequence in gene bank. No variation in deduced amino acids in Egyptian isolate compared to other 10 isolates elsewhere (Fig.3). All sequences are similar with $100 \%$ identity.

\section{Phylogenetic tree}

Phylogenetic tree constructed to $\mathrm{C} 1$ gene of psittacine Circovirus recovered from red rumped parakeet 
showed that the Egyptian isolate sequence was clustered in clade closed to 3 sequences in USA (AY518900.1, AY521234.1 and AY521235.1) and separated from other 5 sequences (Fig. 4).

Amplification of $T$ gene of Polyomavirus in psittacine birds using PCR

$\mathrm{T}$ gene of Polyomavirus was amplified in pooled feather and pooled tissue samples of three species of psittacine birds (parakeet, budgerigar and love birds). PCR results showed a predicted band at $310 \mathrm{bp}$ when electrophoresed and separated in agarose gel (Fig.5). A total of eleven PCR positive feather sample out of 50 birds were positive to Polyomavirus with a total percentage of $22 \%$. Meanwhile, a total of 10 PCR positive samples were recovered from pooled tissue samples with positivity percentage of 20 .

Distribution of Polyomavirus infection in feather sample were higher than in the pooled tissue samples.

Sequence analysis of $T$ gene of Psittacine polyomavirus Nucleotide Sequence

Sequencing and analysis of PCR positive samples to polyomavirus from budgerigar our samples Egypt showed an amplified fragments of $\mathrm{T}$ gene of polyomavirus genome. Analysis of the nucleotide sequence revealed that the sequence was 297 nucleotides long. Blast analysis of $\mathrm{T}$ gene fragment of psittacine polyomavirus revealed 18 similar sequences in gene bank with their accession numbers (Fig 6). When nucleotide sequence of $\mathrm{T}$ gene of polyomavirus was compared to other sequences in gene bank showed $99.3 \%$ to $100 \%$ identity. Only one nucleotide substitution was observed at position 203 and not effect on amino acid translation.

\section{Amino acid sequence}

Alignment of amino acid sequence of Egyptian psittacine polyomavirus with other sequences in gene bank showed 98 amino acids were translated, all translated amino acids were conserved across all the isolates examined. No variation observed at the level of amino acids and identical $(100 \%)$ to all 17 sequence generated from gene bank (fig 7 and table2 ).

Phylogenetic tree

Phylogenetic tree constructed to $\mathrm{T}$ gene of psittacine polyomavirus recovered from Budgergier showed that, the Egyptian isolate sequence was clustered in clade closed to 4 sequences isolated from Germany, Japan, china and Poland but separated from other 13 sequences isolated from Newsland, Japan, China and Poland (Fig 8). 


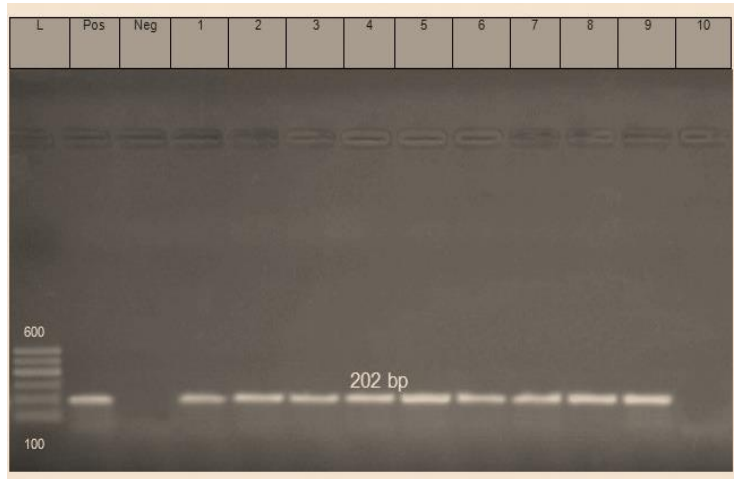

Fig. (1): Gel electrophoresis of C1 gene of Circovirus in psittacine birds

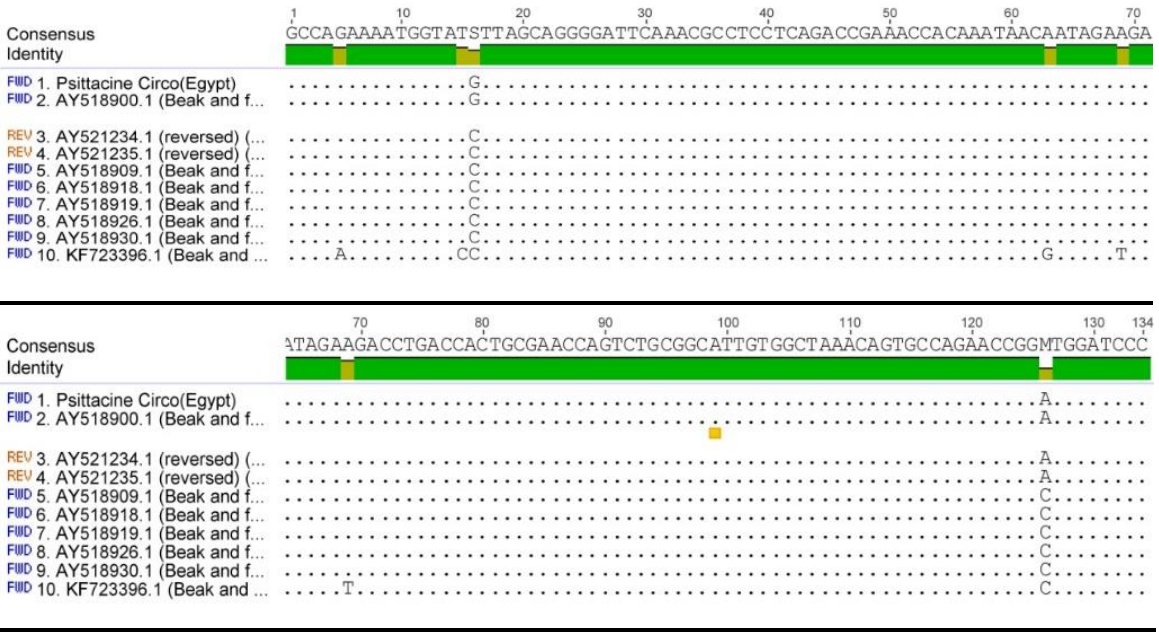

Fig. (2): Nucleotide alignment of $\mathrm{C} 1$ gene sequence of psittacine circovirus with 10 sequences generated from gene bank $(\mathrm{n} 1=1-70, \mathrm{n} 2=71-134)$

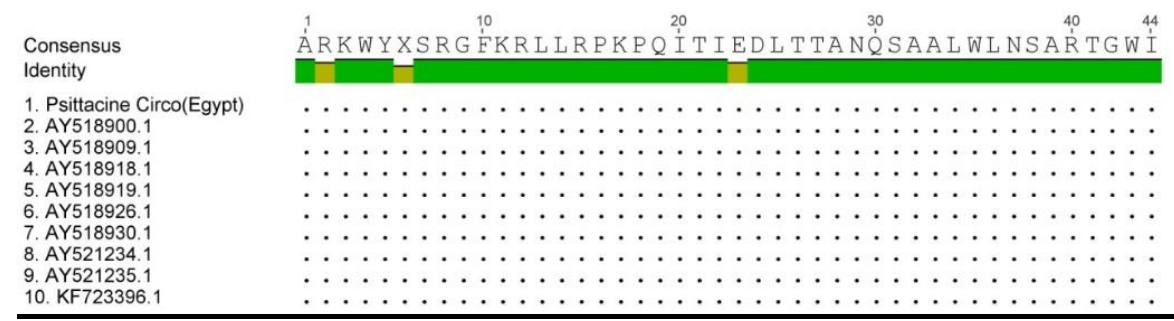

Fig. (3): Amino acid sequence alignment of Egyptian psittacine circovirus with other 10 sequences generated from gene bank. 
Table (1): Nucleotide identity percentages of Egyptian Circovirus isolated from red rumped Parakeet compared to other 10 isolates in gene bank

\begin{tabular}{|c|c|c|c|c|c|c|c|c|c|c|}
\hline Acc. No. & $\begin{array}{c}\text { Circo(Eg } \\
\text { ypt) }\end{array}$ & $\begin{array}{c}\text { AY5189 } \\
00.1\end{array}$ & $\begin{array}{c}\text { AY5212 } \\
34.1\end{array}$ & $\begin{array}{c}\text { AY5212 } \\
35.1\end{array}$ & $\begin{array}{c}\text { AY5189 } \\
09.1\end{array}$ & $\begin{array}{c}\text { AY5189 } \\
18.1\end{array}$ & $\begin{array}{c}\text { AY5189 } \\
19.1\end{array}$ & $\begin{array}{c}\text { AY5189 } \\
26.1\end{array}$ & $\begin{array}{c}\text { AY5189 } \\
30.1\end{array}$ & $\begin{array}{c}\text { KF7233 } \\
96.1 \\
\end{array}$ \\
\hline \multicolumn{2}{|c|}{ Circo(Egypt) } & 100 & 99.3 & 99.3 & 98.5 & 98.5 & 98.5 & 98.5 & 98.5 & 95.5 \\
\hline $\begin{array}{c}\text { AY5189 } \\
00.1\end{array}$ & 100 & & 99.3 & 99.3 & 98.5 & 98.5 & 98.5 & 98.5 & 98.5 & 95.5 \\
\hline $\begin{array}{c}\text { AY5212 } \\
34.1\end{array}$ & 99.3 & 99.3 & & 100 & 99.3 & 99.3 & 99.3 & 99.3 & 99.3 & 96.3 \\
\hline $\begin{array}{c}\text { AY5212 } \\
35.1 \\
\end{array}$ & 99.3 & 99.3 & 100 & & 99.3 & 99.3 & 99.3 & 99.3 & 99.3 & 96.3 \\
\hline $\begin{array}{c}\text { AY5189 } \\
09.1\end{array}$ & 98.5 & 98.5 & 99.3 & 99.3 & & 100 & 100 & 100 & 100 & 97 \\
\hline $\begin{array}{c}\text { AY5189 } \\
18.1 \\
\end{array}$ & 98.5 & 98.5 & 99.3 & 99.3 & 100 & & 100 & 100 & 100 & 97 \\
\hline $\begin{array}{c}\text { AY5189 } \\
19.1\end{array}$ & 98.5 & 98.5 & 99.3 & 99.3 & 100 & 100 & & 100 & 100 & 97 \\
\hline $\begin{array}{c}\text { AY5189 } \\
26.1 \\
\end{array}$ & 98.5 & 98.5 & 99.3 & 99.3 & 100 & 100 & 100 & & 100 & 97 \\
\hline $\begin{array}{c}\text { AY5189 } \\
30.1\end{array}$ & 98.5 & 98.5 & 99.3 & 99.3 & 100 & 100 & 100 & 100 & & 97 \\
\hline $\begin{array}{c}\text { KF7233 } \\
96.1\end{array}$ & 95.5 & 95.5 & 96.3 & 96.3 & 97 & 97 & 97 & 97 & 97 & \\
\hline
\end{tabular}

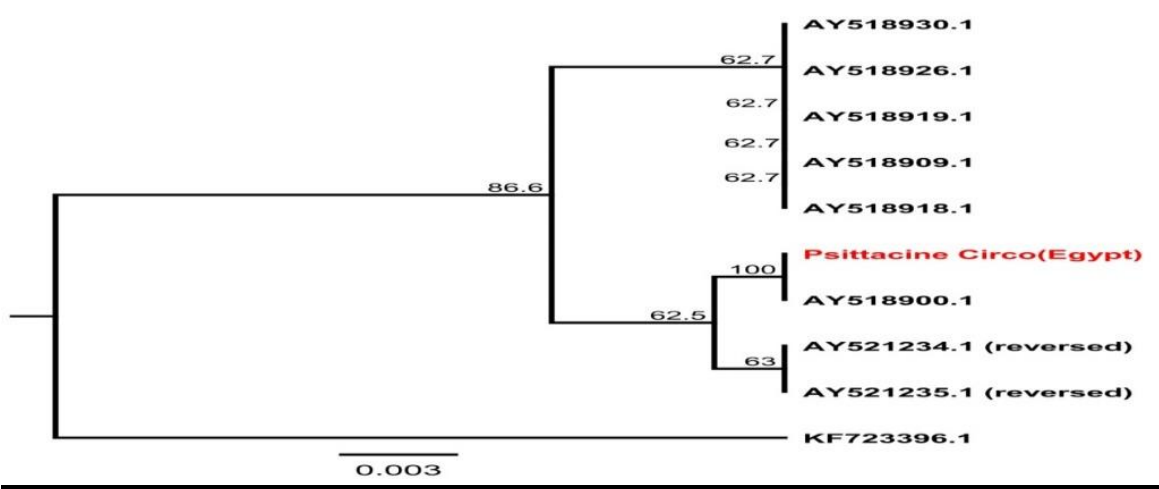

Fig.(4):Phylogenetic tree of C1 gene of Egyptian Psittacine Circovirus based on nucleotide sequence

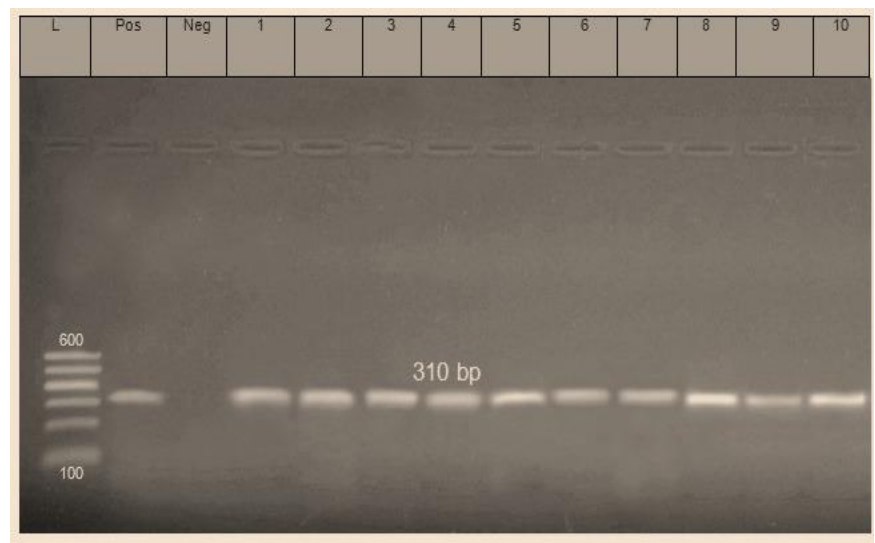

Fig. (5): Gel electrophoresis of $\mathrm{T}$ gene of polyomavirus in feather follicles of psittacine birds 

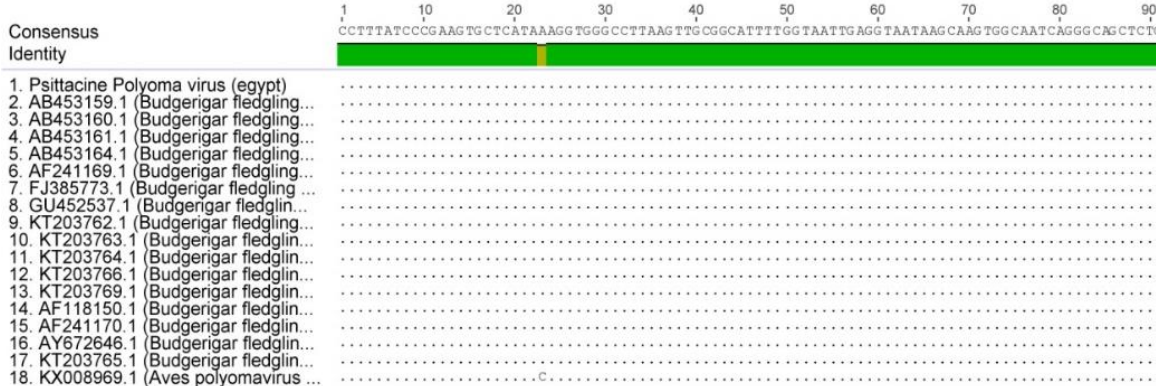

Consensus

1. Psittacine Polyoma virus (egypt)

AB453159.1 (Budgerigar fledgling...

4. AB453160.1 Budgerigar fledgling

5. AB453164.1 Budgerigar fledgling

6. AF241169.1 Budgerigar fledgling...

8. GU452537.1 (Budgerigar fledglin ...

10. KT203763.1 Budgerigar fledglin....

11. KT203764.1 Budgerigar fledgli ...

13. KT203769.1 Budgerigar fledglin ...

14. Ar

16. AY672646.1 Budgerigar fledglin

18. KX008969.1 (Aves polyomavirus...
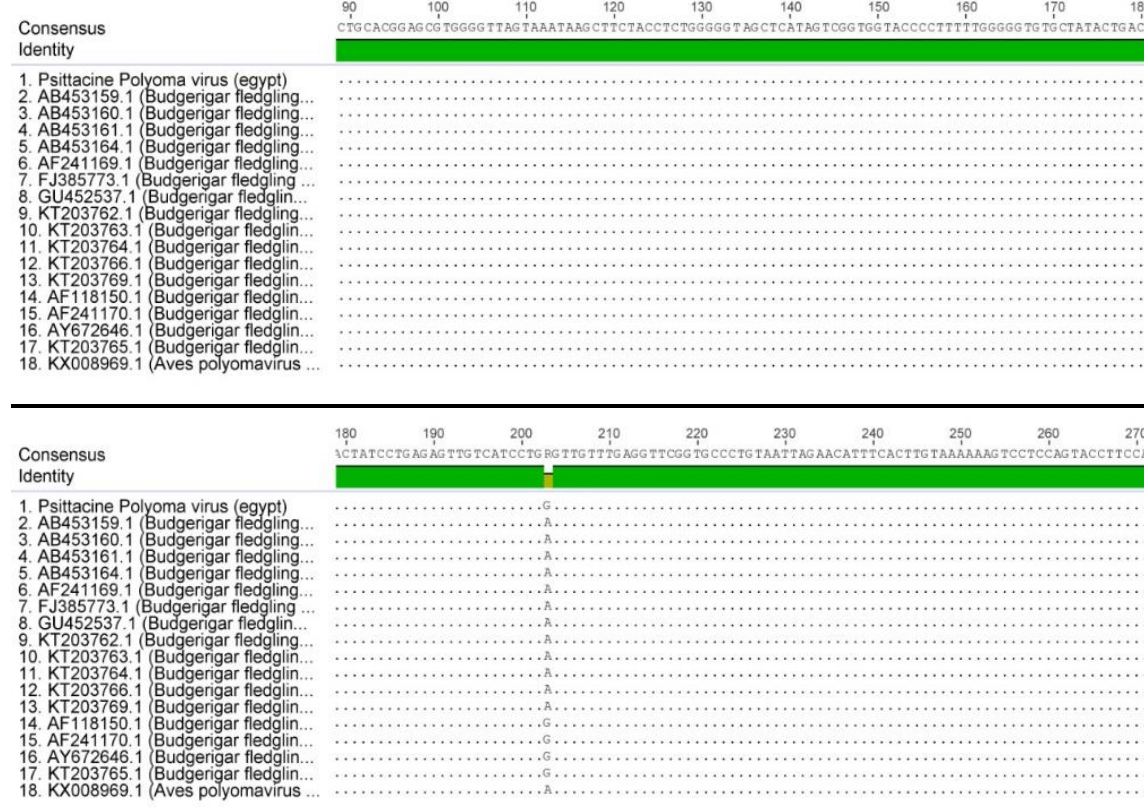

.
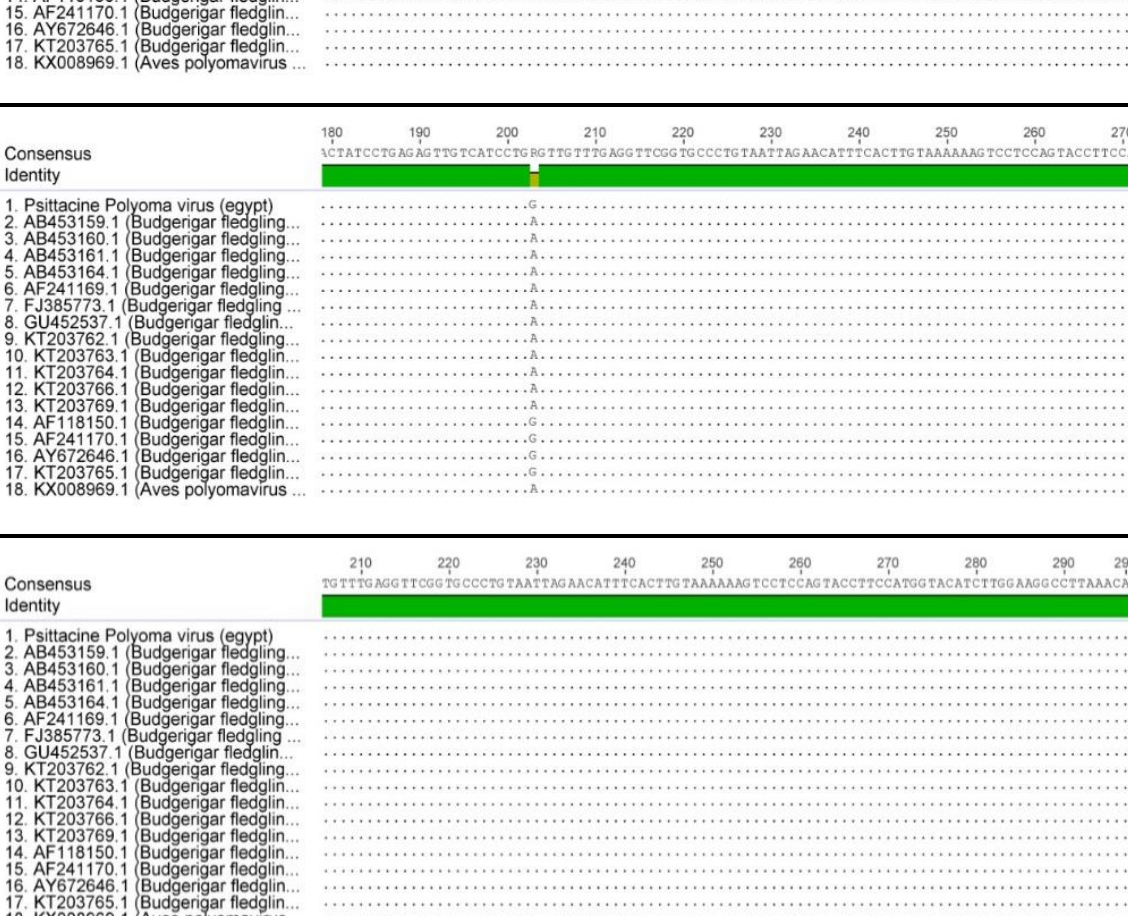

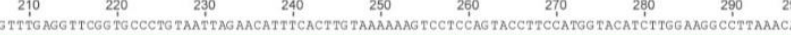

Fig. (6): Nucleotide alignment of T gene sequence of psittacine Polyomavirus with 18 sequences generated from gene bank $(\mathrm{n} 1=1-90, \mathrm{n} 2=91-180, \mathrm{n} 3=181$ $270, \mathrm{n} 4=211-297$ ) 


Consensus
Identity
1. Psittacine Polyoma virus (egypt)
2. AB453159.1
3. AB453160.1
4. AB453161.1
5. AB453164.1
6. AF118150.1
7. AF241169.1
8. AF241170.1
9. AY672646.1
10. FJ385773.1
11. GU452537.1
12. KT203762.1
13. KT203763.1
14. KT203764.1
15. KT203765.1
16. KT203766.1
17. KT203769.1
18. KX008969.1

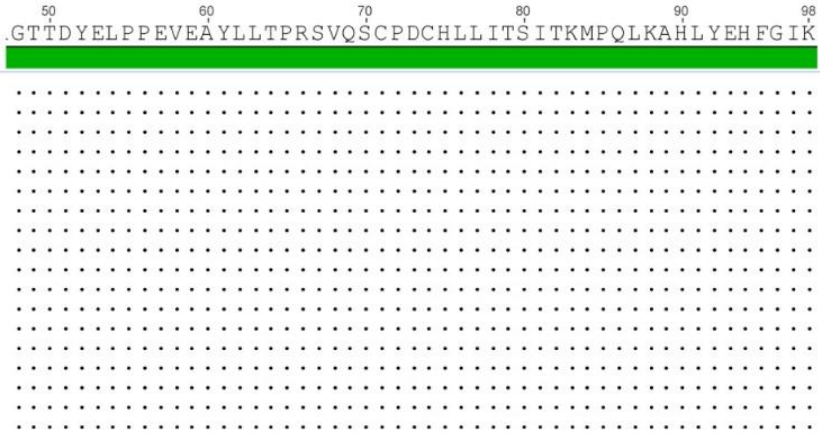

Fig.(7): Amino acid sequence alignment of Egyptian psittacine Polyomavirus with other 18 sequences generated from gene bank.

Table.(2): Nucleotide identity percentages of Egyptian polyomaVirus (T gene) isolated from Budgerigar and compared to 17 polyoma virus sequences in gene bank.

\begin{tabular}{|c|c|c|c|c|c|c|c|c|c|c|c|c|c|c|c|c|c|c|}
\hline & $\begin{array}{c}\begin{array}{c}\text { Polyo } \\
\text { m(eg } \\
\text { ypt })\end{array} \\
\end{array}$ & $\begin{array}{c}\mathrm{AB} \\
453 \\
159 . \\
1 \\
\end{array}$ & $\begin{array}{c}\mathrm{AB} \\
453 \\
160 \\
1 \\
\end{array}$ & $\begin{array}{c}\text { AB } \\
453 \\
161 . \\
1 \\
\end{array}$ & $\begin{array}{c}\mathrm{AB} \\
453 \\
164 . \\
1 \\
\end{array}$ & $\begin{array}{c}\text { AF } \\
241 \\
169 \\
.1 \\
\end{array}$ & $\begin{array}{c}\text { FJ3 } \\
857 \\
73 . \\
1 \\
\end{array}$ & $\begin{array}{c}\text { GU } \\
\mathbf{4 5 2} \\
\mathbf{5 3 7} . \\
1 \\
\end{array}$ & $\begin{array}{c}\text { KT } \\
203 \\
762 . \\
1 \\
\end{array}$ & $\begin{array}{c}\text { KT } \\
203 \\
763 . \\
1 \\
\end{array}$ & $\begin{array}{c}\text { KT } \\
203 \\
764 . \\
1 \\
\end{array}$ & $\begin{array}{c}\text { KT } \\
203 \\
766 . \\
1 \\
\end{array}$ & $\begin{array}{c}\text { KT } \\
203 \\
769 . \\
1 \\
\end{array}$ & $\begin{array}{c}\text { AF } \\
118 \\
150 \\
.1 \\
\end{array}$ & $\begin{array}{c}\text { AF } \\
241 \\
170 \\
.1 \\
\end{array}$ & $\begin{array}{c}\text { AY } \\
672 \\
646 . \\
1 \\
\end{array}$ & $\begin{array}{c}\mathrm{KT} \\
203 \\
765 . \\
1 \\
\end{array}$ & $\begin{array}{c}\text { KX } \\
008 \\
969 . \\
1 \\
\end{array}$ \\
\hline \multicolumn{2}{|c|}{ Polyoma (egypt) } & 99.7 & 99.7 & 99.7 & 99.7 & $\begin{array}{c}99 . \\
7\end{array}$ & $\begin{array}{c}99 . \\
7\end{array}$ & 99.7 & 99.7 & 99.7 & 99.7 & 99.7 & 99.7 & 100 & 100 & 100 & 100 & 99.3 \\
\hline $\begin{array}{c}\text { AB453 } \\
159.1\end{array}$ & 99.7 & & 100 & 100 & 100 & 100 & 100 & 100 & 100 & 100 & 100 & 100 & 100 & 99.7 & 99.7 & 99.7 & 99.7 & 99.7 \\
\hline $\begin{array}{c}\mathrm{AB} 453 \\
160.1\end{array}$ & 99.7 & 100 & & 100 & 100 & 100 & 100 & 100 & 100 & 100 & 100 & 100 & 100 & 99.7 & 99.7 & 99.7 & 99.7 & 99.7 \\
\hline $\begin{array}{c}\text { AB453 } \\
164.1\end{array}$ & 99.7 & 100 & 100 & 100 & & 100 & 100 & 100 & 100 & 100 & 100 & 100 & 100 & 99.7 & 99.7 & 99.7 & 99.7 & 99.7 \\
\hline $\begin{array}{c}\text { AF241 } \\
169.1\end{array}$ & 99.7 & 100 & 100 & 100 & 100 & & 100 & 100 & 100 & 100 & 100 & 100 & 100 & 99.7 & 99.7 & 99.7 & 99.7 & 99.7 \\
\hline $\begin{array}{l}\text { FJ385 } \\
773.1\end{array}$ & 99.7 & 100 & 100 & 100 & 100 & 100 & & 100 & 100 & 100 & 100 & 100 & 100 & 99.7 & 99.7 & 99.7 & 99.7 & 99.7 \\
\hline $\begin{array}{r}\text { KT20 } \\
3763.1\end{array}$ & 99.7 & 100 & 100 & 100 & 100 & 100 & 100 & 100 & 100 & & 100 & 100 & 100 & 99.7 & 99.7 & 99.7 & 99.7 & 99.7 \\
\hline $\begin{array}{l}\text { KT20 } \\
3764.1\end{array}$ & 99.7 & 100 & 100 & 100 & 100 & 100 & 100 & 100 & 100 & 100 & & 100 & 100 & 99.7 & 99.7 & 99.7 & 99.7 & 99.7 \\
\hline $\begin{array}{r}\text { KT20 } \\
3766.1\end{array}$ & 99.7 & 100 & 100 & 100 & 100 & 100 & 100 & 100 & 100 & 100 & 100 & & 100 & 99.7 & 99.7 & 99.7 & 99.7 & 99.7 \\
\hline $\begin{array}{r}\text { KT20 } \\
3769.1\end{array}$ & 99.7 & 100 & 100 & 100 & 100 & 100 & 100 & 100 & 100 & 100 & 100 & 100 & & 99.7 & 99.7 & 99.7 & 99.7 & 99.7 \\
\hline $\begin{array}{c}\text { AF118 } \\
150.1\end{array}$ & 100 & 99.7 & 99.7 & 99.7 & 99.7 & $\begin{array}{c}99 . \\
7\end{array}$ & $\begin{array}{c}99 . \\
7\end{array}$ & 99.7 & 99.7 & 99.7 & 99.7 & 99.7 & 99.7 & & 100 & 100 & 100 & 99.3 \\
\hline $\begin{array}{c}\text { AF241 } \\
170.1\end{array}$ & 100 & 99.7 & 99.7 & 99.7 & 99.7 & $\begin{array}{c}99 . \\
7\end{array}$ & $\begin{array}{c}99 . \\
7\end{array}$ & 99.7 & 99.7 & 99.7 & 99.7 & 99.7 & 99.7 & 100 & & 100 & 100 & 99.3 \\
\hline
\end{tabular}




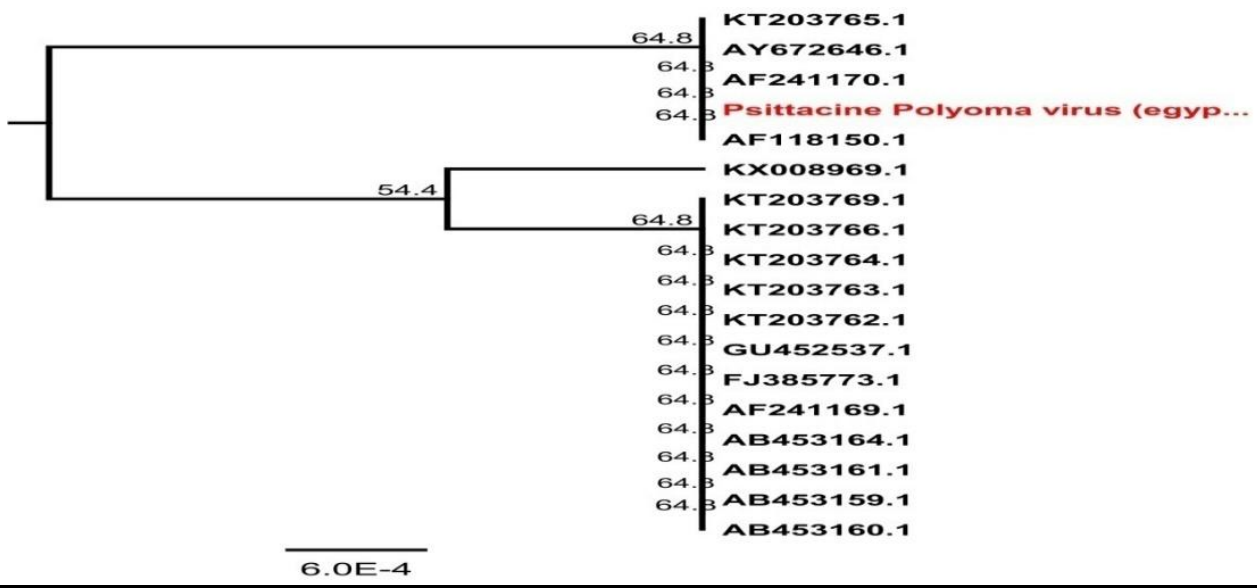

Fig.(8):Phylogenetic tree of T gene of Egyptian Psittacine polyomavirus based on nucleotide sequence

\section{Discussion:}

Infectious viral diseases of psittacine birds are the most common clinical problems in captive psittacine birds because of their association with acute death and difficulties in treatment and control. Among DNA viruses, psittacine beak and feather disease virus (PBFDV) and avian polyomavirus (APV) (Bernier et al 1981 and Phalen et al 1993) are the most important diseases affect a wide range of psittacine birds. In Egypt, information about virus infections in psittacine birds are limited and the objectives of this study were centered about DNA viruses in psittacine birds including PBFDV and APV in red rumped parakeet, budgerigar and love birds with respect to prevalence, clinical features, pathology, epidemiology and diagnosis of both viruses in birds of Egypt.

In this work, PCR was used to amplify $\mathrm{C} 1$ gene encoding capsid protein of Circovirus and $\mathrm{T}$ gene encoding of $\mathrm{T}$ antigen of avian polyomavirus in extracted DNA from psittacine birds using a specific foreword and reverse primers. Total DNA extracted from 50 feather samples and pooled tissue samples were used as template for amplification. The predicted band size for these primers were a PCR product with a size of 202 bp for Circovirus and 302 bp for avian Polyomavirus respectively. The same results were obtained by (Raue et al. 2004 \& Piasecki and Wieliczko 2010). PCR is a sensitive test and the method of choice for the diagnosis of PBFDV infections and avian polyoma infections. Several PCR protocols have been developed (Ypelaar et al., 1999; Kiatipattanasakul-Banlunara et al., 2002; Ritchie et al., 2003). With regard to PBFDV epidemiology, the C1 region coding the capsid proteins might be of particular interest as it should reflect virus host interactions as well as the selective pressure of the immune system. PCR positive results of Circovirus infection and avian Polyomavirus infection in different bird species of Egypt were recorded. Total positivity percentage of 
Circovirus in feather sample (32\%) is higher than pooled tissue samples $(20 \%)$. PCR protocols are known to be labor-saving, time-saving and costsaving. They also reduce the risk of laboratory contamination (Raue et al. 2004). Our PCR prevalence data are similar to those reported by Bert et al., (2005) but much lower compared to those reported by (Rahaus, et al., 2003) who found a much higher prevalence $(39 \%)$ of BFDV DNA in feather samples collected from 146 clinically normal psittacine birds and even non psittacine birds in Germany. In our study, the percent of nucleotide homology of the $\mathrm{C} 1$ coding region fragment of psittacine Circovirus compared to all published $\mathrm{C} 1$ sequences in GenBank ranged from $95.3 \%$ to $100 \%$ (Table 1). Comparative nucleotide sequence analysis of red rumped parakeet strain of PBFDV with ten previously published strains recorded, showed two nucleotide exchanges at positions 16 and 126 but not effect on amino acid translation. Amino acid alignment of Egyptian psittacine Circo virus sequence indicated that the sequence of the $\mathrm{C} 1$ region was $100 \%$ identical to the other 10 published sequences in gene bank .Phylogenetic tree constructed to $\mathrm{C} 1$ gene of psittacine Circovirus recovered from red rumped parakeet bird showed that the Egyptian isolate sequence was clustered in clade closed to 3 sequences in USA (AY518900.1, AY521234.1 and AY521235.1) and separated from other 5 sequences elsewhere. These results supported by (Ritchie et al. 1990) who stated that, PBFDV is a genetically diverse virus and there have broad genotype lineages aligned to the major families of psittacine birds namely the cockatoos, loriids and other parrots. BFDV isolates harvested from a diverse range of psittacine genera were found to be antigenically similar.Phylogenetic tree constructed in this study, based on nucleotide sequences of polyoma $\mathrm{T}$ antigen predicted in, showed that, Egyptian budgerigar strain was clustered in clade closed to 4 sequences isolated from Germany, Japan, china and Poland but separated from other 13 sequences isolated from Newsland, Japan, China and Poland. Avian Polyomavirus in this study showed a broad diversity indicating an independent evolution of these proteins in avian polyomaviruses over a longer period of time, as demonstrated by separate branching in a phylogenetic tree (Johne et al. 2007). Alignment results and blast analysis of Egyptian psittacine polyomavirus suggested that, $\mathrm{T}$ gene of psittacine polyomavirus had a high degree of nucleotide sequence homology with the published APV sequences in GenBank ranging from $99.9 \%$ to $100 \%$ (Table 2). Some researchers have reported a very high degree of similarity revealed by the APV sequences.as reported previously (Rott et al. 1988, Phalen et al. 1999 and Johne et al. 1998). A phylogenetic analysis of the genome sequences of all polyomaviruses shows a separate branching of the polyomaviruses of birds, indicating a separate grouping and phylogenetic development of these viruses (Johne et al. 2006). Analysis of the genome sequences shows that the main 
differences between mammalian and bird polyomavirus genome sequences are found in the large $\mathrm{T}$ antigen encoding region (Phalen et al. 1993).

Finally, Egypt is a large axial and central country in the world for migratory birds and domestic poultry, and therefore infection of birds should be a matter of great importance. Here, in this study, we detected APV and PBFD infection in psittiscine birds through PCR and made an accurate diagnosis of the affected budgerigars, red rumped parakeet and love birds. Sequencing of APV and PBFDV isolates from Egypt will allow the evolutionary pathways of these viruses to be explored. The results of this study will be helpful for further research in the fields of epidemiology and molecular biology, which will have great significance in prevention and control of APV and PBFD infection

Acknowledgements: I would like to express my thanks to virology lab. faculty of Veterinary Medicine, Suez Canal University.

\section{Competing interests:}

None of the authors have any competing interests to declare.

\section{References:}

Bernier, G.; Morin, M.and Morsolais G.(1981): A generalized inclusion body disease in the budgerigar (Melopsittacua undulatus) caused by a papovavirus-like agent. Avian Dis 1981;(25):1083-1092.

Bert, E.; Tomassone, L.; Peccati, C.; Navarrete, M.G. and Sola, S.C.(2005): Detection of beak and feather disease virus (BFDV) and avian polyomavirus (APV) DNA in psittacine birds in Italy. Journal of
Veterinary Medicine, Series B, 52(2): 64-68

Cooper, JE.;Lawtoon,MPC . and greenwood,AG.(1986):papillomas in psittacine birds.vet Rec (119);535-536 Gough, R.E.; Drury, S.E.; Culver, F.; Britton, $P$. and Cavanagh, D.(2006): Isolation of a coronavirus from a green-checked Amazon parrot (Amazona viridigenalis Cassin). Avian Pathology, (35), 122-126

Grund, C.H.; Werner, O.;Gelderblom, H.R.; Grimm, F. and Ko "sters, J. (2002): Avian paramyxovirus serotype 1 isolates from the spinal cord of parrots display a very low virulence. Journal of Veterinary Medicine Series B, (49) 445-451

Johne, R. and Muller, H. (1998): Avian polyomavirus in wild birds: Genome analysis of isolates from Falconiformes and Psittaciformes.Arch. Virol.( 143), $1501 \pm 1512$

Johne, R.; W. Wittig; D. Ferna'ndezde-Luco; U. Ho"fle, and H. Mu"ller. (2006): Characterization of two novel polyomaviruses of birds by using multiply primed rolling-circle amplification of their genomes. J. Virol.( 80):3523-3531

Johne, $R$. and Muller, $J$. (2007):Polyomaviruses of Birds: Etiologic Agents of Inflammatory Diseases in a Tumor Virus Family. Journal of Virology, 81(21), 1155411559.

Kiatipattanasakul-Banlunara W, Tantileartcharoen R, Katayama KI, Suzuki K, Lekdumrogsak T, Nakayama H, Doi K(2002): Psittacine beak and feather disease in three captive sulphur-crested cockatoos 
(Cacatua galerita) in Thailand. J Vet Med Sci. 2002;(64):527-529.

Kistler, A.L.; Gancz, A.; Clubb, S.; Skewes-Cox; P., Fischer K.and Sorber, K. (2008): Recovery of divergent avian bornaviruses from cases of proventricular dilatation disease: identification of a candidate etiologic agent. Virology Journal, (5), 88

Khalesi, B.; Bonne, N.; Stewart ,M.; Sharp, M.and Raidal S. (2005): A comparison of haemagglutination, haemagglutination inhibition and PCR for the detection of psittacine beak and feather disease virus infection and a comparison of isolates obtained from loriids. J Gen Virol( 86):3039-3046.

McDonald, S. E.;Lowenstine, L. J. and Ardans, A. A.(1981): Avian pox in bluefronted Amazon parrots. J. Am. Vet. Med. Assoc., 179(11):1218-22.

Pass D.A.and Perry R.A.(1984): The pathology of psittacine beak and feather disease. Aust. Vet. J. 1984;(61):69-74

Phalen, D.N. and Wilson, V.G.Graham (1993):American jornal veterinary research , 54(12):2040-2047

Phalen, D.N. (1998). Avian polyomavirus. Journal of the American Federation of Aviculture, 25(5), 28-39

Piasecki, T.and Wieliczko, A. (2010): Detection of beak and feather disease virus and avian polyomavirus DNA in psittacine birds in Poland. B Vet I Pulawy 54:141-146

Pillai, S. P.; Suarez, D. L.; PantinJackwood, M. and Lee, C. W.( 2008): Pathogenicity and transmission studies of H5N2 parrot avian influenza virus of Mexican lineage in different poultry species. Vet. Microbiol. 129: 48-57

Rahaus, M. and Wolff, M.H.(2003):Psittacine beak and feather disease: a first survey of the distribution of beak and feather disease virus inside the population of captive psittacine birds in Germany. J Vet Med B Infect Dis Vet Public Health. 2003 Oct;50(8):368-71 Raue, R.; Johne, R.; Crosta, L.; Bürkle, M.; Gerlach, H. and Müller, H.(2004): Nucleotide sequence analysis of a $\mathrm{C} 1$ gene fragment of psittacine beak and feather disease virus amplified by realtime polymerase chain reaction indicates a possible existence of genotypes. Avian Pathol (33): 41- 50

Raue, R.; V. Schmidt; M. Freick; B. Reinhardt; R. Johne; L. Kamphausen; E. F. Kaleta; H. Müller, and M. E. Krautwald-Junghanns. 2005.: A disease complex associated with pigeon circovirus infection, young pigeon disease syndrome. Avian Pathol.( 34):418-425

Ritchie, B.W.; Niagro, F.D.; Latimer, K.S.; Lukert, P.D.; Steffens, W.L.;Rakich, P.M. and Pritchard, N. (1990): Ultrastructural, protein composition, and antigenic comparison of psittacine beak and feather disease virus purified from four genera of psittacine birds. Journal of Wildlife Diseases, (26):196-303.

Ritchie, P. A.; Anderson, I. L. and Lambert, D. M. (2003): Evidence for specificity of psittacine beak and feather disease viruses among avian hosts. Virology( 306), 109-115

Rott, O.; Kro\$ ger, M.; Mu\$ ller, H. and Hobom, G. (1988): The genome of budgerigar - edgling disease virus, an avian polyomavirus. Virology (165),74 786 .

Simpson, C.F.; Hanley, J.E. and Gaskin, J.M. (1975): Psittacine herpesvirus infection resembling Pacheco's parrot disease. Journal of Infectious Diseases, (131), 390-39

Standley, DM.;(2013):MAFFT multiple sequence alignment software version 7 : improvements in performance and 
usability .Mol Biol Evol. 2013 Van den Brand; J. R. Manvell; P. Apr;30(4):772-80

Tamura K, Peterson D, Peterson N, Stecher G, Nei M, Kumar S. MEGA5(2011): molecular evolutionary genetics analysis using maximum likelihood, evolutionary distance, and maximum parsimony methods. Mol Biol Evol. (28):27312739

Todd, D. (2004): Avian circovirus diseases: lessons for the study of PMWS. Veterinary Microbiology, (98), 169-174

Guntram; MJ Kik and G.M .Dorrestein. (2007): Reovirus infections associated with high mortality in psittaciformes in The Netherlands. Avian Pathol (36), 293299.

Ypelaar, I.; Bassami, M.R.; Wilcox, G.E.and Raidal, S.R.(1999): A universal polymerase chain reaction for the detection of psittacine beak and feather disease virus. Veterinary Microbiology( 68), 141-148.

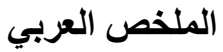

نظر أ لأهميه طيور الزينه فى الاستمتاع برؤيتها و إستئناسها و إستخدامها للزينه وتربيتها فى المنازل

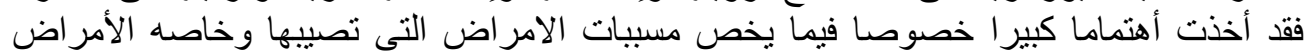

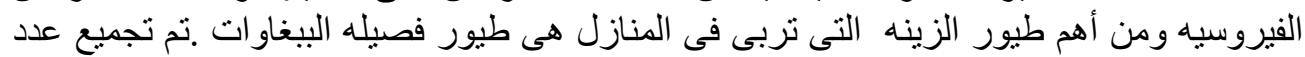

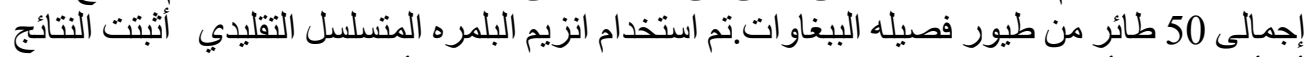

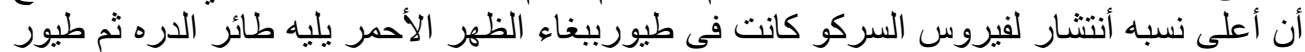

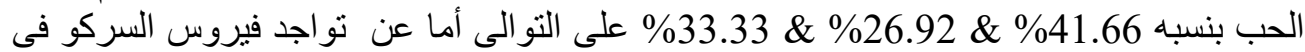

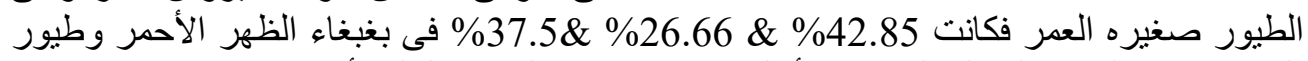

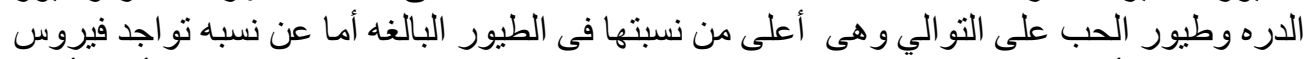

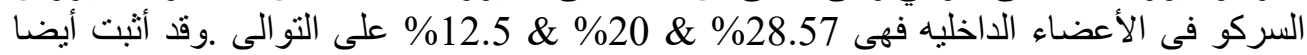

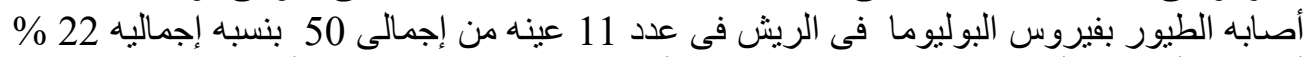

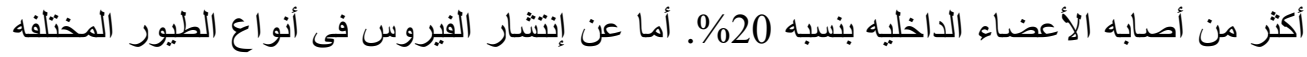

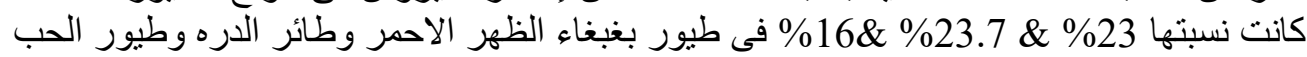

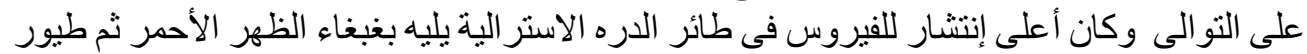

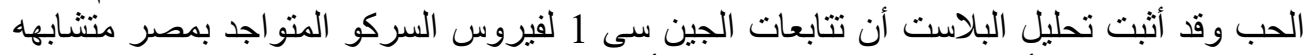

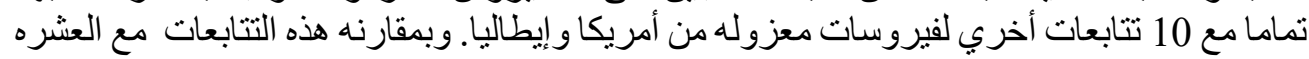

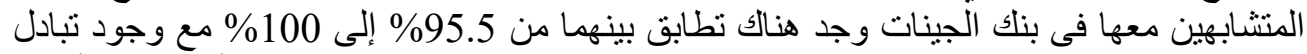

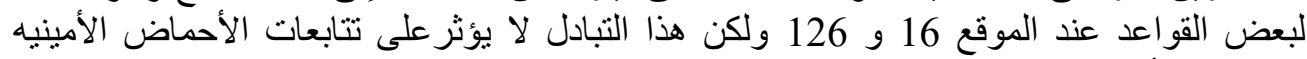

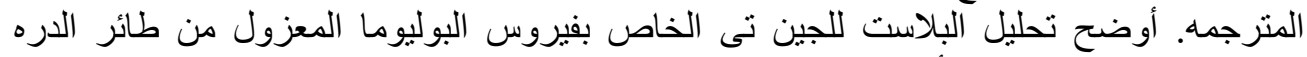

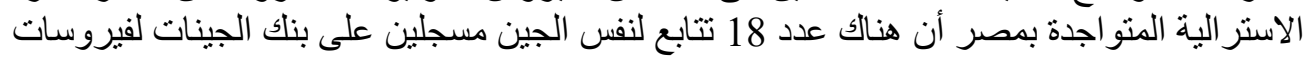

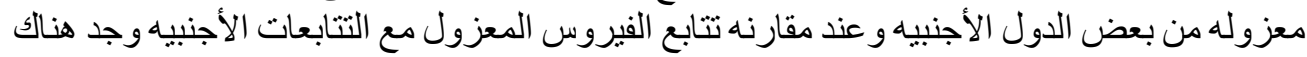

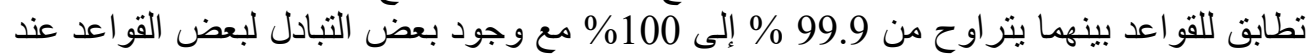
الموقع 203 فقط لكنها لاتؤثر على الأحماض الأمينيه المترجمه 